\title{
MODEL ANALISIS PRE-DEFINED SINGLE LINGKAGE CLUSTERING PADA SISTEM REKOMENDASI OBYEK WISATA DI KOTA SEMARANG
}

\author{
Dwi Budi Santoso', Dewi Handayani U. $\mathbf{N}^{2}$, Saefurrohman ${ }^{3}$ \\ ${ }^{1,2,3}$ Faculty Information Technology, Stikubank University \\ email: ${ }^{1}$ dbs@edu.unisbank.ac.id, ${ }^{2}$ dewi_h@edu.unisbank.ac.id, ${ }^{3}$ saefurr@edu.unisbank.ac.id
}

\begin{abstract}
Abstrak
Perjalanan wisata selalu berkaitan dengan bagaimana seorang wisatawan mengunjungi obyek wisata berdasar kebutuhan informasi tentang rute yang harus dilalui ke obyek wisata yang diinginkan dan transportasi apa saja yang bisa digunakan berdasar waktu yang dimiliki. Petunjuk arah juga sangat diperlukan untuk kemudahan akses perjalanan.

Model analisis pre-defined singkle-linkage dilakukan untuk menentukan obyek mana saja yang memiliki lokasi berdekatan bisa membentuk satu klaster dan kunjungan dilakukan berdasar jarak paling dekat dengan klaster menuju klaster berikutnya sesuai dengan kelompok jenis obyek wisata. Perhitungan jarak antar obyek dengan pengguna menggunakan metode Euclidean Distance untuk mencari jarak berdasar ketetanggaan terdekat.

Hasil analisis penentuan obyek wisata di kota Semarang dengan metode pre-defined single-linkage divisualisasikan menggunakan dendrogram yang bisa menggambarkan kelompok obyek dalam satu klaster berdasar ketetanggaan terdekat. Dari dendrogram bisa dilihat jumlah klaster yang terbentuk dari 14 obyek wisata.
\end{abstract}

Kata Kunci: analisa klastering, pre-defined single linkage, metode nearest neighbour, rute obyek wisata, dendrogram

\section{PENDAhULUAN}

Perjalanan wisata selalu berkaitan dengan bagaimana seorang wisatawan menggunjungi obyek wisata dengan berdasar kebutuhan informasi tentang rute yang harus dilalui untuk melakukan kunjungan ke obyek wisata yang diinginkan. Petunjuk arah juga sangat diperlukan untuk kemudahan akses perjalanan. Kebutuhan informasi tentang seberapa banyak obyek wisata yang bisa dikunjungi dan bisa dijangkau sesuai dengan waktu yang dimiliki.

Pada saat seorang wisatawan ingin mengunjungi sebuah obyek wisata, hal pertama yang dilakukan adalah membuka internet untuk mendapatkan informasi yang dibutuhkan. Website selalu memberikan informasi yang sama pada wisatawan yang berbeda, tanpa memperhatikan kebutuhan personal masing-masing wisatawan. Data yang diberikan kepada wisatawan bisa sesuai dengan permintaan, kebutuhan dan minat, diperlukan satu sistem rekomendasi yang bisa memberikan beberapa alternatif rekomendasi yang membuat situs pariwisata menjadi lebih cerdas [1].

Kebutuhan untuk menentukan rute yang bisa dilalui berdasar posisi pengguna berada dengan jarak terdekat dari klaster obyek wisata yang terbentuk dengan mengelompokkan berdasarkan kesamaan jenis obyek wisata.

Clustering merupakan teknologi yang digunakan utnuk menemukan pola-pola tersembunyi. Obyek-obyek data dikelompokkan dalam kelompok kemiripan yang disebut cluster. Dalam satu cluster obyek-obyek data didalamnya memiliki kemiripan satu sama lain dan antar cluster memiliki perbedaan [3]. Untuk mengelompokkan obyek-obyek wisata yang berdekatan membentuk satu klaster menggunakan analisa klaster dengan metode Hierarchical Aglomerative Cluster (HAC). 
Analisa klaster yang merupakan salah satu teknik data mining bertujuan mengidentifikasi sekelompok obyek yang mempunyai kemiripan karakteristik tertentu dapat dipisahkan dengan kelompok obyek lainnya, sehingga obyek berada pada kelompok yang berbeda.

Metode nearest neighbour merupakan salah satu metode yang digunakan pada teknologi clustering. Pengelompokan dimulai dengan mengelompokkan dua obyek yang memiliki jarak yang terdekat menjadi satu cluster [3]. Proses pengelompokkan dilanjutkan ke obyek-obyek dengan jarak obyek yang semakin jauh, sampai akhirnya semua obyek terhubung menjadi sebuah rute. Analisis jarak terdekat yang bisa dikunjungi berdasarkan posisi wisatawan berada dibanding dengan posisi terdekat pada klaster. Wisatawan akan mendapatkan rekomendasi informasi urutan obyek yang dapat dikunjungi sesuai dengan klaster peruntukan obyek wisata. Pengelompokkan juga dapat diatur seberapa jauh perjalanan yang akan ditempuh dan memakan waktu berapa lama.

Pemodelan kembali rute optimal yang dihasilkan dari urutan waktu kunjungan menggunakan single linked list dengan titik awal dari obyek yang dituju dengan metode penentuan titik awal dimulai dari user berada.

Obyek wisata yang dijadikan acuan dalam perhitungan untuk analisis jarak paling dekat obyek wisata yang bisa dijangkau oleh pengguna terdiri dari beberapa obyek wisata sesuai dengan pembagian peruntukan yang bisa mewakili klaster yang diidentifikasi. Data yang digunakan sebagai sampel pemodelan diambil dari beberapa obyek wisata yang biasa dikunjungi oleh wisatawan ke kota Semarang sejumlah 14 obyek wisata dengan posisi (berdasar koordinat latitude dan longitude) yang dirasa bisa mewakili kunjungan yaitu:

Tabel 1. Obyek Wisata Di Semarang Dengan Posisi Latitude dan Longitude

\begin{tabular}{|r|l|r|r|}
\hline \multirow{2}{*}{ No } & \multicolumn{2}{|c|}{ Obyek Wisata } & \multicolumn{2}{c|}{ Koordinat } \\
\cline { 3 - 4 } & & \multicolumn{1}{c|}{ Latitude } & \multicolumn{1}{c|}{ Longitude } \\
\hline 1 & Lawang Sewu & -6.9844579 & 110.4077796 \\
\hline 2 & Stasiun Tawang & -6.973959 & 110.4094061 \\
\hline 3 & Stasiun Besar Poncol & -6.9787517 & 110.408679 \\
\hline 4 & Klenteng Sam Po kong & -6.9888498 & 110.3996613 \\
\hline 5 & Masjid Agung Jawa Tengah (Baiturrahman) & -6.986011 & 110.4295715 \\
\hline 6 & Masjud Agung Jawa Tengah (MAJT) & -7.0086145 & 110.4121065 \\
\hline 7 & Masjid Besar Kauman & -6.9778208 & 110.4120934 \\
\hline 8 & Museum Ronggowarsito & -6.9859542 & 110.3838605 \\
\hline 9 & Museum Mandala Bakti & -6.9847668 & 110.4087782 \\
\hline 10 & Candi Tugu & -6.9787612 & 110.3292208 \\
\hline 11 & Gereja Blenduk & -6.9743371, & 110.4093101 \\
\hline 12 & Kawasan Kota Lama & -6.9684447 & 110.4259028 \\
\hline 13 & Pagoda Buddhagaya & -7.0862474, & 110.409091 \\
\hline 14 & Gedung Marba & -6.9696509 & 110.4225325 \\
\hline
\end{tabular}

Untuk mengetahui jarak antar obyek dengan posisi terdekat dengan pengguna menggunakan metode Euclidian Distance dan berdasar layanan google map.

Melakukan predefine single linked list metode nearest neighbour berdasar posisi wisatawan berada dengan klaster obyek wisata terdekat di kota Semarang.

Penelitian tentang analisa klastering dengan metode Single Linked list sudah banyak dilakukan sebelumnya. Sebagai salah satu metode IR, clustering melakukan pengelompokan data berdasarkan cluster/kelas dan merupakan teknik untuk mengorganisasikan data yang tidak terstruktur tersebut menjadi suatu struktur data yang mempunyai nilai informasi tertentu. Tujuan dari algoritma ini adalah untuk mengelompokkan dokumen yang memiliki kesamaan 
(similarity) ke dalam satu cluster tertentu. Bisa dikatakan bahwa dokumen dalam satu cluster akan memiliki relevansi satu sama lain, tetapi tidak memiliki relevansi dengan dokumen di dalam cluster lain. Dalam proses yang baik, data yang dihasilkan dalam satu cluster akan memiliki tingkat kesamaan yang tinggi, dan akan memiliki nilai kesamaan yang rendah dengan cluster yang lainnya.

Clustering melakukan pengelompokan data tanpa berdasar pada kelas data tertentu yang sudah ditetapkan dari awal. Proses ini sangat berbeda dengan proses pada classification yang pada awal proses harus memberikan kelas-kelas data. Sehingga clustering sering disebut dengan pengelompokan data yang tidak terstruktur.

Dalam algoritma clustering, biasanya diperlukan fungsi jarak yang digunakan untuk mengukur jarak (kemiripan suatu data dengan data yang lain). Beberapa fungsi jarak yang dapat digunakan dalam proses clustering adalah:

a. Euclidean Distance, merupakan perhitungan jarak dengan menggunakan 2 keadaan.

b. Manhattan Distance, disebut juga dengan taxicap-norm, yang menghitung jarak dengan menggunakan 1 keadaan.

c. Mahalanobis Distance, merupakan fungsi jarak yang digunakan untuk menghitung data dalam skala dan korelasi yang berbeda.

Analisis cluster termasuk dalam analisis multivariat yang mewakili seluruh hubungan interdependensi, tidak ada perbedaan variabel bebas dan variabel tak bebas (independent and dependent variables) dalam analisis ini. "Analisis cluster adalah teknik yang digunakan untuk mengidentifikasi objek atau individu yang serupa dengan memperhatikan beberapa kriteria" [4]. Analisis cluster merupakan bagian penting dari teknologi data mining untuk menemukan pola distribusi data yang menarik dalam data potensial dalam kondisi tanpa pengalaman sebelumnya [9]. Analisis cluster merupakan teknik multivariat yang mempunyai tujuan utama untuk mengelompokan objek-objek berdasarkan karakteristik yang dimilikinya.

Analisis cluster mengklasifikasi objek sehingga setiap objek yang paling dekat kesamaanya dengan objek lain berada dalam cluster yang sama. Kelompok-kelompok yang terbentuk memiliki homogenitas internal yang tinggi dan heterogenitas eksternal yang tinggi. Berbeda dengan teknik multivariat lainya, analisis ini tidak mengestimasi set variabel secara empiris sebaliknya menggunakan set variabel yang ditentukan oleh peneliti itu sendiri. Fokus dari analisis cluster adalah membandingkan objek berdasarkan set variabel, hal inilah yang menyebabkan para ahli mendefinisikan set variabel sebagai tahap kritis dalam analisis cluster. Set variabel cluster adalah suatu set variabel yang mempresentasikan karakteristik yang dipakai objek-objek.

Analisis cluster dilakukan untuk tujuan:

a. Menggali data/eksplorasi data,

b. Mereduksi data menjadi kelompok data baru dengan jumlah lebih kecil atau dinyatakan dengan pengkelasan (klasifikasi) data,

c. Menggeneralisasi suatu populasi untuk memperoleh suatu hipotesisis dan,

d. Menduga karakteristik data-data.

Algoritma klaster harus mampu dimplementasikan pada berbagai macam bentuk data seperti data nominal, ordinal maupun gabungannya dimana tujuan utama analisis cluster adalah mengelompokan objek-objek berdasarkan kesamaan karakteristik diantara objek-objek tersebut [5].

Clustering adalah studi formal metode dan algoritma untuk partisi atau pengelompokan. Analisis clustering tidak menggunakan pelabelan kategori sebelumnya. Clustering bersifat unsupervised learning atau tidak mempunyai tahap pelatihan data, berbeda dengan klasifikasi [6]. 
Pada saat seorang wisatawan ingin mengunjungi sebuah obyek wisata, hal pertama yang dilakukan adalah membuka internet untuk mendapatkan informasi yang dibutuhkan. Untuk menyampaikan informasi, website selalu memberikan informasi yang sama pada wisatawan yang berbeda, tanpa memperhatikan kebutuhan personal masing-masing wisatawan. Supaya sektor pariwisata lebih efektif dan efesien, data yang diberikan kepada wisatawan seharusnya sesuai permintaan, kebutuhan dan minat. Penerapan sistem rekomendasi akan membuat situs pariwisata lebih cerdas [1].

Metode nearest neighbour menggunakan jarak tetangga terdekat untuk mengukur ketidakmiripan antara dua kelompok, termasuk dalam kategori agglomerative (bottom up) clustering, yang akan menghasilkan dendrogram(tree) dari tingkat yang paling bawah, menggabungkan dua cluster yang paling mirip pada tiap tingkat(level) untuk menuju ke tingkat yang lebih tinggi. Proses berulang sampai semua kelompok data digabungkan menjadi satu cluster [2].

\section{Jarak Euclidean}

Jarak Euclidean adalah besarnya jarak suatu garis lurus yang menghubungkan antar objek. Misalkan ada dua objek yaitu A dengan koordinat (x1,y1) dan B dengan koordinat $(\mathrm{x} 2, \mathrm{y} 2)$ maka jarak antar kedua objek tersebut dapat diukur dengan rumus kuran jarak atau ketidaksamaan antar objek ke-i dengan objek ke-j, disimbolkan dengan dij dan k=1,..,p. Nilai dij diperoleh melalui perhitungan jarak kuadrat Euclidean sebagai berikut:

$$
\begin{gathered}
d_{i j}=\sqrt{\sum_{k=i}^{F}\left(x_{i k}-x_{j k}\right)^{2}} \\
\sqrt{\left(x_{1}-x_{2}\right)^{2}+\left(y_{1}-y_{2}\right)^{2}}
\end{gathered}
$$

Keterangan:

dij =Jarak Kuadrat Euclidean antar objek ke-i dengan objek ke-j

$\mathrm{P}=$ Jumlah variabel cluster

Xik =Nilai atau data dari objek ke-i pada variabel ke-k

$\mathrm{Xjk}=$ Nilai atau data dari objek ke-j pada variabel ke-k [6].

\section{METODE PENELITIAN}

\section{a. Hierarchical Agglomerative Clustering (HAC)}

Hierarchical Clustering adalah metode analisis kelompok yang berusaha untuk membangun sebuah hirarki kelompok data. Strategi pengelompokannya umumnya ada 2 jenis yaitu Agglomerative (Bottom-Up) dan Devisive (Top-Down). (Pada bagian ini akan dibatasi hanya menggunakan konsep Agglomerative).

HAC mengasumsikan satu fungsi untuk menentukan kesamaan/kemiripan dua kejadian. Salah satunya juga bisa mengasumsikan satu fungsi kesamaan dan sebaliknya dalam beberapa operasi ( seperti jarak minimal $\rightarrow$ maksimal kemiripan) dalam algoritma untuk membangun kesamaan. Contoh Algoritma HAC adalah sebagai berikut:

\section{b. Fungi Jarak Euclidean Distance}

Euclidean distance adalah sebuah metode yang digunakan untuk mengukur jarak (distance). Euclidean distance sebenarnya merupakan generalisasi dari teorema phytagoras.

Berikut ini adalah contoh perhitungan dengan menggunakan Euclidean Distance. Jika terdapat dua buah titik pada sebuah bidang dua dimensi $\left(R^{2}\right) . u=\left(x_{1}, y_{1}\right)$ dan $v=\left(x_{2}, y_{2}\right)$ maka untuk mengukur jarak dari kedua belah titik tersebut dapat digunakan persamaan phytagoras. 
$d=\sqrt{(x 1-x 2)^{2}+(y 1-y 2)^{2}}$

$\mathrm{x}_{1}, \mathrm{x}_{2}=$ koordinat sumbu $\mathrm{x}$ dari sebuah titik

$\mathrm{y}_{1}, \mathrm{y}_{2}=$ koordinat sumby y dari sebuah titik

Jarak tersebut menyebabkan sebuah metrik pada $\mathrm{R}^{2}$, yang disebut sebagai Euclidean metric pada $\mathrm{R}^{2}$. Bila terdapat dua buah vektor dengan $\mathrm{n}$ dimensi, $\mathrm{a}=\left(a_{1}, a_{2}, \ldots, a_{\mathrm{n}}\right)$ dan $\mathrm{b}=\left(b_{1}\right.$, $\left.b_{2}, \ldots, b_{\mathrm{n}}\right)$ maka formula phytagoras dapat digeneralisasi ke dalam $\mathrm{n}$ dimensi $\left(\mathrm{R}^{2}\right)$ menjadi:

$\mathrm{d}=\sqrt{\left(a_{1}-b_{1}\right)^{2}+\left(a_{2}-a_{2}\right)^{2}}+\cdots\left(a_{n}-b_{n}\right)^{2}$

Perhatikan kemiripan dari dua buah formula diatas. Formula Euclidean Distance juga merupakan metric pada $\mathrm{R}^{\mathrm{n}}$, dikenal sebagai Euclidean Space:

Berikut ini adalah bentuk umum dari Euclidean Distance:

$\left.d=\left(\sum_{n=1}^{N}\left(x_{n}-y_{n}\right) p\right) 1 / p\right)$

$\mathrm{N}=$ jumlah dimensi vektor

$x, y=$ vektor

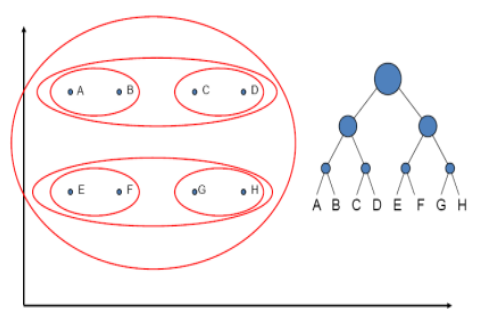

Gambar 1. Contoh algoritma HAC

Algoritma Agglomerative Hierarchical Clustering :

a. Matrik Jarak antar data.

b. langkah c dan d higga hanya satu kelompok yang tersisa.

c. Gabungkan dua kelompok terdekat berdasarkan parameter kedekatan yang ditentukan.

d. Matrik Jarak antar data untuk merepresentasikan kedekatan diantara kelompok baru dan kelompok yang masih tersisa.

e. Selesai.

\section{HASIL DAN PEMBAHASAN}

\section{a. Perhitungan Fungsi Jarak}

Untuk menentukan jarak paling dekat dengan ketetanggan terdekat antar obyek untuk menghasilkan klaster dihitung berdasarkan posisi kordinat obyek wisata berdasar (latitude, longitude) yang diberikan di tabel 2. Ada 14 obyek wisata yang dijasikan sampel data untuk dilakukan analisis menggunakan metode single linkage HAC.

Tabel 2. Perhitungan Jarak User ke Obyek

\begin{tabular}{|l|c|c|c|c|}
\hline \multicolumn{1}{|c|}{ User } & -6.988327 & 110.4148582 & \multicolumn{2}{c|}{ Jarak user ke obyek } \\
\hline & & & $\begin{array}{c}\text { Euclidean } \\
\text { Distance }\end{array}$ & $\begin{array}{c}\text { Google } \\
\text { Map }\end{array}$ \\
\hline Lawang Sewu & -6.9840506 & 110.4077796 & 0.9 & 1.1 \\
\hline Stasiun Tawang & -6.9644338 & 110.4257718 & 2.9 & 3.3 \\
\hline Stasiun Besar Poncol & -6.9729977 & 110.4125928 & 1.7 & 2.5 \\
\hline Klenteng Sam Po kong & -6.9960734 & 110.3967853 & 2.2 & 3.3 \\
\hline Masjid Agung Jawa Tengah (MAJT) & -6.9834409 & 110.4429559 & 3.2 & 4.4 \\
\hline Masjud (Baiturrahman) & -6.9891405 & 110.4202544 & 0.6 & \\
\hline Masjid Besar Kauman & -6.9724511 & 110.420478 & 1.9 & 2.2 \\
\hline Museum Ronggowarsito & -6.9859489 & 110.3816718 & 3.7 & 4.1 \\
\hline
\end{tabular}




\begin{tabular}{|l|c|c|c|c|}
\hline Museum Mandala Bakti & -6.9847668 & 110.4087782 & 0.8 & 1.1 \\
\hline Candi Tugu & -6.9787612 & 110.329221 & 9.6 & 10.5 \\
\hline Gereja Blenduk & -6.9743371 & 110.4093101 & 1.7 & 3.3 \\
\hline Kawasan Kota Lama & -6.9684447 & 110.4259028 & 2.5 & 3.2 \\
\hline Pagoda Buddhagaya & -7.0862474 & 110.409091 & 10.9 & 17.5 \\
\hline Gedung Marba & -6.9696509 & 110.4225325 & 2.2 & 3.2 \\
\hline
\end{tabular}

Sebagai perbandingan untuk perhitungan jarak berdasar posisi user berada (sebagai acuan dipakai posisi pengguna berada di UNISBANK dengan posisi latitude, longitude $=-6.9883268$, 110.4148582).

Tabel 3. Koordinat Posisi Obyek Wisata

\begin{tabular}{|r|l|r|r|}
\hline \multirow{2}{*}{ No } & \multicolumn{2}{|c|}{ Obyek Wisata } & \multicolumn{2}{c|}{ Koordinat } \\
\cline { 3 - 4 } & & Latitude & \multicolumn{1}{c|}{ Longitude } \\
\hline 1 & Lawang Sewu & -6.9844579 & 110.4077796 \\
\hline 2 & Stasiun Tawang & -6.973959 & 110.4094061 \\
\hline 3 & Stasiun Besar Poncol & -6.9787517 & 110.408679 \\
\hline 4 & Klenteng Sam Po kong & -6.9888498 & 110.3996613 \\
\hline 5 & Masjid Agung Jawa Tengah (Baiturrahman) & -6.986011 & 110.4295715 \\
\hline 6 & Masjud Agung Jawa Tengah (MAJT) & -7.0086145 & 110.4121065 \\
\hline 7 & Masjid Besar Kauman & -6.9778208 & 110.4120934 \\
\hline 8 & Museum Ronggowarsito & -6.9859542 & 110.3838605 \\
\hline 9 & Museum Mandala Bakti & -6.9847668 & 110.4087782 \\
\hline 10 & Candi Tugu & -6.9787612 & 110.3292208 \\
\hline 11 & Gereja Blenduk & -6.9743371, & 110.4093101 \\
\hline 12 & Kawasan Kota Lama & -6.9684447 & 110.4259028 \\
\hline 13 & Pagoda Buddhagaya & -7.0862474, & 110.409091 \\
\hline 14 & Gedung Marba & -6.9696509 & 110.4225325 \\
\hline
\end{tabular}

Perhitungan jarak dimulai dari posis user berada $\left(\mathrm{d}_{\text {user }}=-6.9883268,110.4148582\right)$

\section{b. Perbandingan Jarak Berdasar Euclidean Distance Dengan Google Map}

Perbandingan jarak dilakukan untuk melihat realitas jarak tempuh dengan perhitungan fungsi jarak menggunakan Euclidean Distance dengan jarak yang dihasilkan dari Google Map yang diberikan dibawah ini

Perhitungan fungsi jarak Euclidian Distance dengan berdasar perhitungan secara diagonal dengan fungsi Phytagoras sehingga jarak yang diperoleh secara langsung ditarik garis lurus pada dua titik lokasi (diwakili dengan koordinat) dan dihitung. Sedangkan untuk jarak tempuh berdasar google map merupakan perhitungan yang dilakukan berdasarkan panjang jalan yang bisa dilalui.

1) Klasterisasi Obyek Wisata

Klasterisasi obyek wisata yang akan dikunjungi berdasar jarak terdekat pertama yang bisa dijangkau oleh pemakai ditentukan sebagai titik awal perhitungan untuk menentukan dalam klaster mana saja yang dihasilkan sesuai dengan batasan jarak tempuh yang diharapkan oleh wisatawan.

2) Perhitungan Jarak Antar Obyek

Proses clustering dengan metode single linkage merupakan penggabungan dua objek atau lebih yang mempunyai jarak terdekat. Proses pengklasteran dihitung dengan matrik jarak adalah sebagai beikut:

(a) Matrik 14 x 14 dibuat yang mewakili 14 obyek wisata. Langkah pertama mencari jarak antara dua obyek untuk semua kemungkinan obyek yang ada. Tahap berikutnya dari 
setengah matrik (diagonal) dicari jarak yang paling pendek. Jarak dari Lawang Sewu dan Museum Mandala Bakti dengan jarak terdekat $0.1 \mathrm{~km}$, kedua objek tersebut menjadi satu cluster dan membentuk cluster baru. Baris dan kolom yang berhubungan Lawang Sewu dan Museum Mandala Bakti dihilangkan kemudian dijadikan satu menjadi Lawang Sewu/Museum Mandala Bakti, sehingga tersisa 13 cluster yang membetuk matriks yang baru. Kemudian dilakukan perbaikan matriks jarak menggunakan metode single linkage dengan persamaan:

$$
\mathrm{h}\left(B_{r}, B_{s}\right)=\min \left\{d\left(x_{i}, x_{j}\right) ; x_{i} \text { anggota } B_{r}, x_{j} \text { anggota } B_{s}\right.
$$

Hasil perhitungan semua jarak dari ke 14 titik lokasi adalah sebagai berikut:

Tabel 4. Proses klasterisasi Lawang Sewu-Museum Mandala Bakti

\begin{tabular}{|c|l|c|c|c|c|c|c|c|c|c|c|c|c|c|c|}
\hline No & \multicolumn{1}{|c|}{ Wisata Religi } & 1 & 2 & 3 & 4 & 5 & 6 & 7 & 8 & 9 & 10 & 11 & 12 & 13 & 14 \\
\hline 1 & Masjid Baiturrahman & 0.0 & 1.5 & 1.9 & 2.6 & 1.4 & 2.0 & 4.3 & 2.4 & 10.2 & 2.8 & 2.2 & 2.0 & 10.9 & 2.7 \\
\hline 2 & Lawang Sewu & 1.5 & 0.0 & 1.8 & 0.1 & 0.1 & 1.5 & 0.3 & 2.5 & 0.8 & 3.1 & 2.3 & 1.7 & 16.1 & 1.9 \\
\hline 3 & Masjid Kauman Semarang & 1.9 & 1.8 & 0.0 & 1.7 & 1.9 & 0.3 & 2.1 & 0.6 & 1.0 & 1.3 & 0.4 & 0.1 & 17.9 & 3.7 \\
\hline 4 & Masjid Agung MAJT & 2.6 & 0.1 & 1.7 & 0.0 & 0.2 & 1.4 & 0.4 & 2.4 & 0.7 & 3.0 & 2.2 & 1.6 & 16.2 & 2.0 \\
\hline 5 & Museum Mandala Bakti & 1.4 & 0.1 & 1.9 & 0.2 & 0.0 & 1.6 & 0.2 & 2.6 & 0.9 & 3.2 & 2.4 & 1.9 & 16.0 & 1.8 \\
\hline 6 & Gereja Bledug( Kristen) & 2.0 & 1.5 & 0.3 & 1.4 & 1.6 & 0.0 & 1.8 & 0.9 & 0.7 & 1.6 & 0.7 & 0.2 & 17.6 & 3.4 \\
\hline 7 & Museum Ronggowarsito & 4.3 & 0.3 & 2.1 & 0.4 & 0.2 & 1.8 & 0.0 & 2.8 & 1.1 & 3.4 & 2.6 & 2.0 & 15.8 & 1.6 \\
\hline 8 & Kawasan Kota Lama & 2.4 & 2.5 & 0.6 & 2.4 & 2.6 & 0.9 & 2.8 & 0.0 & 1.6 & 0.6 & 0.2 & 0.7 & 18.5 & 4.3 \\
\hline 9 & Candi tugu & 10.2 & 0.8 & 1.0 & 0.7 & 0.9 & 0.7 & 1.1 & 1.6 & 0.0 & 2.3 & 1.4 & 0.9 & 16.9 & 2.7 \\
\hline 10 & Stasiun Tawang Stasiun Poncol & 2.8 & 3.1 & 1.3 & 3.0 & 3.2 & 1.6 & 3.4 & 0.6 & 2.3 & 0.0 & 0.8 & 1.3 & 19.2 & 5.0 \\
\hline 11 & Gedung Marba & 2.2 & 2.3 & 0.4 & 2.2 & 2.4 & 0.7 & 2.6 & 0.2 & 1.4 & 0.8 & 0.0 & 0.5 & 18.4 & 4.2 \\
\hline 12 & Stasiun Poncol & 2.0 & 1.7 & 0.1 & 1.6 & 1.9 & 0.2 & 2.0 & 0.7 & 0.9 & 1.3 & 0.5 & 0.0 & 17.8 & 3.6 \\
\hline 13 & Pagoda Buddha Gaya & 10.9 & 16.1 & 17.9 & 16.2 & 16.0 & 17.6 & 15.8 & 18.5 & 16.9 & 19.2 & 18.4 & 17.8 & 0.0 & 14.2 \\
\hline 14 & Klenteng Sam Po Kong & 2.7 & 1.9 & 3.7 & 2.0 & 1.8 & 3.4 & 1.6 & 4.3 & 2.7 & 5.0 & 4.2 & 3.6 & 10.0 & 0.0 \\
\hline
\end{tabular}

Di sini yang mengalami perubahan adalah jarak yang melibatkan cluster baru (cluster yang anggotanya Lawang Sewu (lokasi ke-2) dan Museum Mandala Bakti (lokasi ke-5)) sehingga diperoleh sebagai berikut:

$$
\begin{aligned}
d(2 / 5) 1 & =\min \{d 21, d 51\} \\
& =\min \{1.5,1.4\} \\
& =1.4 \\
d(2 / 5) 3 & =\min \{d 23, d 53\} \\
& =\min \{1.8,1.9\} \\
& =1.8 \\
d(2 / 5) 4 & =\min \{d 24, d 114\} \\
& =\min \{0.1,0.2\} \\
& =0.1 \\
d(2 / 5) 6 & =\min \{d 26, d 56\} \\
& =\min \{1.5,1.6\} \\
& =1.5 \\
d(2 / 5) 7 & =\min \{d 27, d 57\} \\
& =\min \{0.3,0.2\} \\
& =0.2 \\
d(2 / 5) 8 & =\min \{d 28, d 58\} \\
& =\min \{2.5,2.6\}
\end{aligned}
$$




$$
\begin{aligned}
& =2.5 \\
d(2 / 5) 9 & =\min \{d 29, d 59\} \\
& =\min \{0.8,0.9\} \\
& =0.8 \\
d(2 / 5) 10 & =\min \{d 210, d 510\} \\
& =\min \{3.1,3.2\} \\
& =3.1 \\
d(2 / 5) 11 & =\min \{d 211, d 511\} \\
& =\min \{2.3,2.4\} \\
& =2.3 \\
d(2 / 5) 12 & =\min \{d 212, d 512\} \\
& =\min \{1.7,1.9\} \\
& =1.7 \\
d(2 / 5) 13 & =\min \{d 213, d 513\} \\
& =\min \{16.1,16.0\} \\
& =16.1 \\
d(2 / 5) 14 & =\min \{d 214, d 514\} \\
& =\min \{1.9,1.8\} \\
& =1.8
\end{aligned}
$$

Dari hasil perbandingan dengan mencari nilai minimal dihasilkan matrik baru yang merupakan representasi dari klaster (lawang sewu-Museum Mandala). Dari matrik di cari nilai minimal baru yang digambarkan dengan tabel 5 .

Tabel 5. Proses klasterisasi Masjid Kauman-Gedung Marba

\begin{tabular}{|c|c|c|c|c|c|c|c|c|c|c|c|c|c|}
\hline No & $2 / 5$ & $\mathbf{1}$ & $\mathbf{3}$ & $\mathbf{4}$ & $\mathbf{6}$ & $\mathbf{7}$ & $\mathbf{8}$ & $\mathbf{9}$ & $\mathbf{1 0}$ & $\mathbf{1 1}$ & $\mathbf{1 2}$ & $\mathbf{1 3}$ & $\mathbf{1 4}$ \\
\hline $2 / 5$ & 0 & $\mathbf{1 . 4}$ & $\mathbf{1 . 9}$ & $\mathbf{3 . 8}$ & $\mathbf{1 . 1}$ & $\mathbf{2 . 9}$ & $\mathbf{2 . 6}$ & $\mathbf{8 . 8}$ & $\mathbf{2 . 9}$ & $\mathbf{2 . 3}$ & $\mathbf{1 . 3}$ & $\mathbf{1 1 . 3}$ & $\mathbf{1 . 8}$ \\
\hline 1 & $\mathbf{1 . 4}$ & 0.0 & 1.9 & 2.6 & 2.0 & 4.3 & 2.4 & 10.2 & 2.8 & 2.2 & 2.0 & 10.9 & 2.7 \\
\hline 3 & $\mathbf{1 . 9}$ & 1.9 & 0.0 & 2.8 & 1.3 & 4.6 & 0.8 & 10.2 & 1.1 & 0.4 & 0.9 & 12.7 & 3.7 \\
\hline 4 & $\mathbf{3 . 8}$ & 2.6 & 2.8 & 0.0 & 3.9 & 6.8 & 2.5 & 12.7 & 2.9 & 2.7 & 3.6 & 12.0 & 5.3 \\
\hline 6 & $\mathbf{1 . 1}$ & 2.0 & 1.3 & 3.9 & 0.0 & 3.3 & 2.0 & 8.9 & 2.1 & 1.6 & 0.4 & 12.5 & 2.8 \\
\hline 7 & $\mathbf{2 . 9}$ & 4.3 & 4.6 & 6.8 & 3.3 & 0.0 & 5.3 & 5.9 & 5.5 & 4.9 & 3.7 & 11.6 & 2.0 \\
\hline 8 & $\mathbf{2 . 6}$ & 2.4 & 0.8 & 2.5 & 2.0 & 5.3 & 0.0 & 10.8 & 0.4 & 0.4 & 1.6 & 13.2 & 4.5 \\
\hline 9 & $\mathbf{8 . 8}$ & 10.2 & 10.2 & 12.7 & 8.9 & 5.9 & 10.8 & 0.0 & 10.9 & 10.4 & 9.3 & 14.9 & 7.8 \\
\hline 10 & $\mathbf{2 . 9}$ & 2.8 & 1.1 & 2.9 & 2.1 & 5.5 & 0.4 & 10.9 & 0.0 & 0.7 & 1.7 & 13.7 & 4.8 \\
\hline 11 & $\mathbf{2 . 3}$ & 2.2 & 0.4 & 2.7 & 1.6 & 4.9 & 0.4 & 10.4 & 0.7 & 0.0 & 1.2 & 13.1 & 4.1 \\
\hline 12 & $\mathbf{1 . 3}$ & 2.0 & 0.9 & 3.6 & 0.4 & 3.7 & 1.6 & 9.3 & 1.7 & 1.2 & 0.0 & 12.6 & 3.1 \\
\hline 13 & $\mathbf{1 1 . 3}$ & 10.9 & 12.7 & 12.0 & 12.5 & 11.6 & 13.2 & 14.9 & 13.7 & 13.1 & 12.6 & 0.0 & 10.1 \\
\hline 14 & $\mathbf{1 . 8}$ & 2.7 & 3.7 & 5.3 & 2.8 & 2.0 & 4.5 & 7.8 & 4.8 & 4.1 & 3.1 & 10.1 & 0.0 \\
\hline
\end{tabular}

(b) Dengan demikian matrik jarak menjadi seperti dalam tabel 5 Dari matrik jarak pada tabel 4.5 kembali mencari jarak terdekat. Jarak terdekat yang diperoleh adalah jarak antara Masjid Kauman (Lokasi ke-3) dengan Gedung Marba (Lokasi ke-11) yaitu $0.4 \mathrm{~km}$, sehingga Masjid Kauman dan Gedung Marba menjadi 1 klaster. Sekarang tersisa 10 obyek/klaster. Kemudian dilakukan kembali perbaikan matrik jarak menggunakan persamaan singlelinkage.

(c) Proses perhitungan dilakukan sama seperti diatas sampai menghasilkan matrik dengan dua obyek. 
Hasil perhitungan akhir membentuk satu klaster saja dengan keanggotaan \{Candi TuguPagoda Buddha Gaya \} diberikan di tabel 6 dengan jarak $14.9 \mathrm{~km}$. Untuk memperjelas proses penggabungan satu demi satu dapat digambarkan dalam bentuk Dendogram yang dilistrasikan pada gambar 2 berikut ini.

Tabel 6. Proses Akhir Klaster

\begin{tabular}{|c|c|c|}
\hline No & 9 & 13 \\
\hline 9 & 0.0 & 14.9 \\
\hline 13 & 14.9 & 0.0 \\
\hline
\end{tabular}

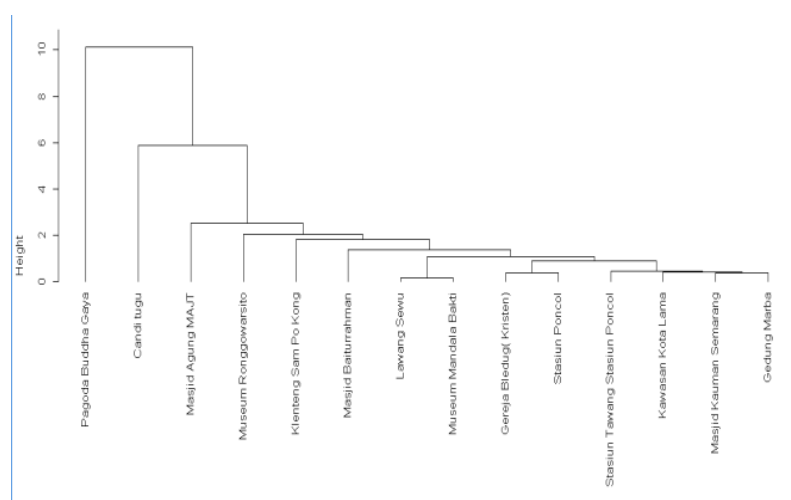

Gambar 2. Dendrogram Wisata Kota Semarang

Gambar 2 menunjukkan dendrogram semua klaster yang terbentuk dari proses perhitungan. Dari dendrogram bisa dilihat jumlah cluster yang terbentuk dari 14 obyek wisata. Setiap kelompok yang terbentuk berdasar ketetanggaan terdekat sehingga dihasilkan klaster dengan keanggotaan sebagai berikut:

a. Klaster pertama dengan keanggotaan \{Masjid Kauman Semarang, Gedung Marba\} yang berada dalam satu klaster,

b. Klaster kedua dengan jarak yang berdekatan membentuk klaster baru dengan keanggotaan \{Masjid Kauman Semarang, Gedung Marba\} dengan \{Kawasan Kota Lama, Stasiun Tawang\},

c. Klaster ketiga yang terbentuk \{gereja Bleduk, Stasiun Poncol \}

d. Klaster keempat (Lawang Sewu- Museum Mandala Bakti \}

e. Klaster keenam gabungan dari keanggotaan\{gereja Bleduk, Stasiun Poncol\}dengan \{Masjid Kauman Semarang, Gedung Marba, Kawasan Kota Lama, Stasiun Tawang\},

f. Klaster ketujuh dengan keanggotaan $\{$ \{masjid Baiturrahman\}\{Lawang Sewu, Museum Mandala Bakti\}\{Gereja Bleduk, Stasiun Poncol $\}\{$ Kawasan Kota Lama, Masjid Kauman, Gedung Marba\}\}

g. Klaster kedelapan dengan keanggotaan \{Klenteng Sam Pokong $\}\{\{\{$ masjid Baiturrahman $\}$ \{Lawang Sewu, Museum Mandala Bakti\}\{Gereja Bleduk, Stasiun Poncol $\}\{$ Kawasan Kota Lama, Masjid Kauman, Gedung Marba\}\}

h. Klaster kesembilan dengan keanggotaan $\{\{$ museum ronggowarsito $\}\{\{$ Klenteng Sam Pokong $\}$ \{masjid Baiturrahman $\}\{$ Lawang Sewu, Museum Mandala Bakti $\}\{$ Gereja Bleduk, Stasiun Poncol\} \{Kawasan Kota Lama, Masjid Kauman, Gedung Marba\}\}

i. Klaster kesepuluh $\{\{$ Masjid Agung MAJT $\}\{\{$ museum ronggowarsito $\}\{\{$ Klenteng Sam Pokong $\}$ \{masjid Baiturrahman $\}\{$ Lawang Sewu, Museum Mandala Bakti $\}\{$ Gereja Bleduk, Stasiun Poncol $\}\{$ Kawasan Kota Lama, Masjid Kauman, Gedung Marba\}\}

j. Klaster kesebelas $\{\{$ candi Tuggu $\}\{\{$ Masjid Agung MAJT $\}\{\{$ museum ronggowarsito $\}$ $\{\{$ Klenteng Sam Pokong $\}\{$ masjid Baiturrahman $\}\{$ Lawang Sewu, Museum Mandala 
Bakti $\}\{$ Gereja Bleduk, Stasiun Poncol $\}\{$ Kawasan Kota Lama, Masjid Kauman, Gedung Marba\}\}

k. Klaster keduabelas $\{\{$ Pagoda Buddha Gaya $\}\{$ candi Tuggu $\}\{\{$ Masjid Agung MAJT $\}\{\{$ museum ronggowarsito $\}\{\{$ Klenteng Sam Pokong $\}\{$ masjid Baiturrahman $\}$ \{Lawang Sewu, Museum Mandala Bakti\}\{Gereja Bleduk, Stasiun Poncol\}\{Kawasan Kota Lama, Masjid Kauman, Gedung Marba\}\}

Berdasarkan Klaster yang ada bisa digunakan untuk mencari jarak paling dekat yang bisa dilakukan oleh pengguna (mengunjungi obyek wisata yang berada dalan satu klaster) dengan memberikan batasan/kontrain untuk melihat obyek mana saja yang bisa dikunjungi dengan satu satuan jarak yang dimiliki.

Misal pengguna memberikan batasan waktu yang diinginkan untuk waktu kunjungan dengan jarak $1 \mathrm{~km}$, obyek mana saja yang bisa dilakukan kunjungan berdasar jarak paling dengan dengan posisi pengguna berada. Hasil analisis bisa dilihat di gambar 3 .

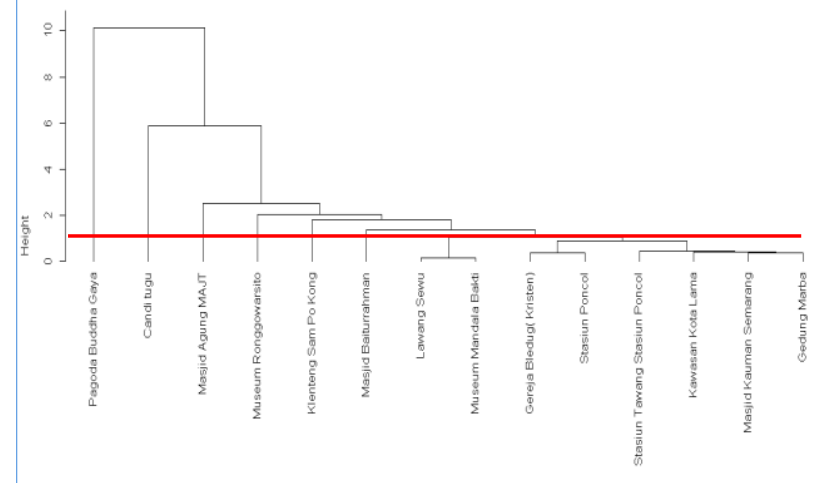

Gambar 3. Dendrogram Wisata Dengan Batasan $1 \mathrm{~km}$

Saat diberikan batasan $1 \mathrm{~km}$, maka terlihat bahwa terbentuk 8 cluster yakni cluster \{Gedung Marba, Masjid Kauman, Kawasan Kota Lama, Gereja Blenduk, Stasiun Poncol\}, \{Museum Mandala Bakti, Lawang Sewu\},\{Masjid Baiturrahman\},\{Klenteng Sam Po Kong\}, \{Museum Ronggowarsito\}, \{Masjid Agung\}, \{Candi Tugu\} dan \{Pagoda Budha Gaya\}. Pengguna dapat memilih cluster yang paling dekat dengan lokasinya, dan cluster yang berdekatan dengan cluster yang dikunjungi. Pengguna juga dapat menaikkan batasan untuk melihat perubahan jumlah cluster, misalnya batasan dinaikkan menjadi $2 \mathrm{~km}$ seperti pada gambar 4.

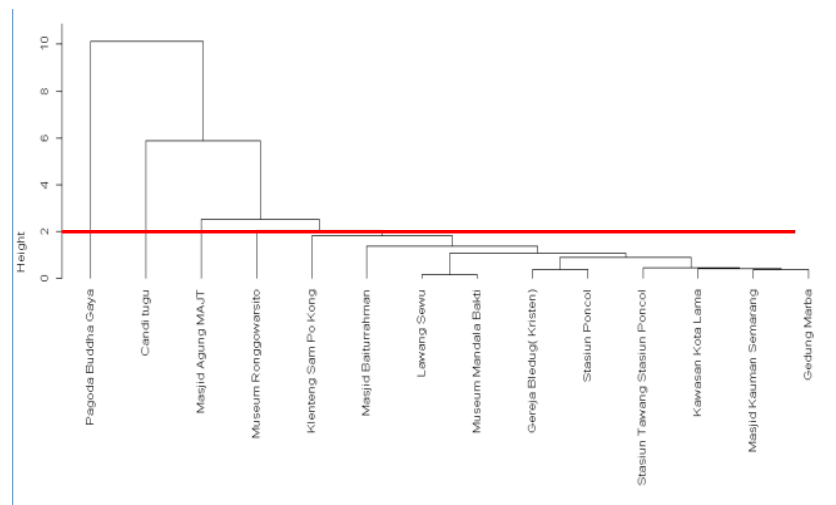

Gambar 4. Dendrogram Wisata Dengan Batasan 2 km

Saat diberikan batasan $2 \mathrm{~km}$, maka terlihat bahwa terbentuk 5 cluster yakni cluster \{Gedung Marba, Masjid Kauman, Kawasan Kota Lama, Gereja Blenduk, Stasiun Poncol, Museum Mandala Bakti, Lawang Sewu, Masjid Baiturrahman, Klenteng Sam Po Kong\}, \{Museum Ronggowarsito\}, \{Masjid Agung\}, \{Candi Tugu\} dan \{Pagoda Budha Gaya\}. 
Dengan menaikkan batasan, maka terlihat bahwa jumlah cluster menjadi berkurang, tetapi jumlah obyek dalam satu cluster menjadi bertambah. Sehingga obyek yang bisa dikunjungi oleh pengguna juga menjadi lebih banyak.

Untuk menvisualisasikan klaster yang terbentuk bisa menggunakan HeatMapDendrogram. Heatmap sangat membantu dalam memvisualisasikan data yang sangat besar dalam clustering, cluster yang berdekatan akan divisualkan dengan tingkat kontras warna yang rendah. Semakin jauh jarak cluster maka semakin tinggi tingkat kontras warna. Contohnya adalah obyek wisata Mandala Bakti yang berwarna kuning berjarak sangat jauh dengan Pagoda Budha gaya yang berwarna merah.

Visualisasi warna yang tingkat kekontrasannya berbeda (otliner) sama sekali dengan klaster yang lain, bisa dikatakan bakwa klaster tersebut berada di posisi Terluar dari kelompok klaster yang ada. Di gambar 5 di berikan contoh klaster dengan keanggotaan \{Pagoda Budhha Gaya, Candi Tugu\}.

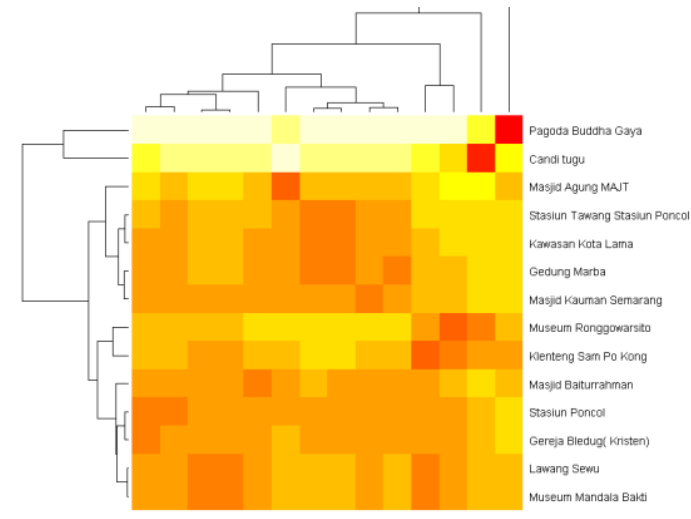

Gambar 5. Heatmap-Dendrogram

\section{KESIMPULAN}

a. Model ini dapat memberikan saran bagi pengguna kumpulan obyek yang harus dikunjungi berdasarkan ketersediaan waktu dengan batasan jarak maksimum antar cluster

b. Jumlah cluster fleksibel berdasarkan kebutuhan pengguna

c. Heatmap memudahkan pengguna dalam melihat cluster obyek wisata yang akan dikunjungi

d. Semakin tinggi nilai batasan, jumlah klaster yang dihasilkan akan semakin sedikit, dan sebaliknya

\section{SARAN}

a. Dibutuhkan algoritma lain dengan obyek data yang sama sehingga dapat dihasilkan cluster yang lebih baik

b. Dapat dikembangkan menjadi sistem rekomendasi berdasarkan jarak sesungguhnya, bukan berdasarkan perhitungan euclidean distance

\section{DAFTAR PUSTAKA}

[1] Agarwal, J., Sharma, N., Kumar, P., Parshav, Vishesh, Srivastava, A., Goudar, R.H., 2013, "Intelligent search in E-Tourism services using Recommendation System: Perfect guide for tourist," Intelligent Systems and Control (ISCO), 2013 7th International Conference on, vol. 410, no. 415, pp. 4-5 Jan 
[2] Gerharz, M., de Waal, C., Martini, P., James, P., 2003, "A cooperative nearest neighbours topology control algorithm for wireless ad hoc networks," Computer Communications and Networks, 2003. ICCCN 2003. Proceedings. The 12th International Conference on, vol. 412, no. 417 , pp. 20-22

[3] Liu, B., 2009, Web Data Mining : Exploring Hyperlinks,Contents, and Usage Data, Springer, Heidelberg, Germany

[4] Kuncoro, M. 2003. Metode Riset untuk Bisnis dan Ekonomi . Jakarta: Penerbit Erlangga

[5] Han, J., Kamber, M., Pei, J.: Data Mining Concept and Techniques, 3rd ed. Morgan Kaufmann-Elsevier, Amsterdam (2012)

[6] Jain. A.K 2009. Data Clustering: 50 Years Beyond K-Means. Pattern Recognition Letters, 2009.

[7] Johnson and wichern. 2007., Applied Multivariate Statistical Analysis (6th Edition), Prentice Hall.

[8] Shafiee, S.. Shafiee, H., 2014, "Studying the effective factors on domestic tourists trust in offering e-services in e-tourism: Case study Iran Country," e-Commerce in Developing Countries: With Focus on e-Trust (ECDC), 2014 8th International Conference on , vol. 1, no. 9, pp. 24-25

[9] Yang,W.,Miao,R.,2014," The Application of Cluster Analysis in the Classification of China's Modern Service Industries",

[10] Zhang, M., Chen, Y., Zhang, X., Lai, J., 2009 "Study on the Recommendation Technology for Tourism Information Service," Computational Intelligence and Design, 2009. ISCID '09. Second International Symposium on, vol.1, no. 415, pp. 12-14 